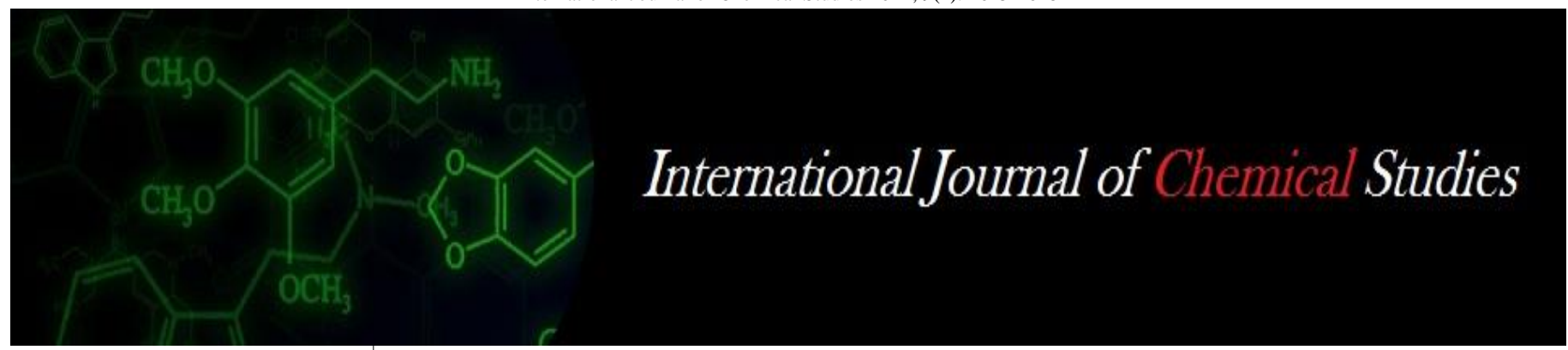

P-ISSN: 2349-8528

E-ISSN: 2321-4902

www.chemijournal.com

IJCS 2021; 9(1): 2625-2628

(C) 2021 IJCS

Received: 07-10-2020

Accepted: 17-11-2020

Archi Jaiswal

M.Tech, Department of

Processing and Food

Engineering, College of

Technology and Engineering,

MPUAT, Udaipur, Rajasthan,

India

\section{PS Champawat}

Department of Processing and

Food Engineering, College of

Technology and Engineering,

MPUAT, Udaipur, Rajasthan,

India

\section{VD Mudga}

Department of Processing and Food Engineering, College of Technology and Engineering, MPUAT, Udaipur, Rajasthan India

\section{SK Jain}

Department of Processing and Food Engineering, College of Dairy and Food Technology, Udaipur, Rajasthan, India
Corresponding Author: Archi Jaiswal

M.Tech, Department of Processing and Food

Engineering, College of Technology and Engineering, MPUAT, Udaipur, Rajasthan, India

\section{Studies on drying characteristics of (Tinospora cordifolia) Giloy stem}

\author{
Archi Jaiswal, PS Champawat, VD Mudgal and SK Jain
}

DOI: https://doi.org/10.22271/chemi.2021.v9.i1ak.11622

\begin{abstract}
Natural drug from the plants are gaining popularity because of several advantages such as often fewer side effect, better patient tolerance, relatively less expensive and acceptance due to a long history of use, especially herbal medicines provide rational means for the treatment of many diseases that are obstinate and incurable in other system of medicine. Drying practices are important in giloy for increased active principle retrieval through improved post-harvest processing. Convective tray dryer was used for drying of Giloy stem using. Three different air temperature and air velocity was taken as a process parameters. The effect of these process parameters on the drying characteristics of (Tinospora cordifolia) giloy stem was studied. The effect of dryring air temperature and air velocity on drying time was quite evident. The initial drying rate was maximum i.e. $0.039278 \mathrm{~g} \mathrm{w} / \mathrm{g} \mathrm{dm}-\mathrm{min}$ at $60^{\circ} \mathrm{C}$ air temperature and $2 \mathrm{~m} / \mathrm{s}$ air velocity and was minimum $0.0275 \mathrm{~g} \mathrm{w} / \mathrm{g} \mathrm{dm}-\mathrm{min}$ at $40{ }^{\circ} \mathrm{C}$ and $1 \mathrm{~m} / \mathrm{s}$ air velocity. The maximum drying rate was observed at initial stage of drying for all air temperatures and velocity and the drying rate decreased with drying time.
\end{abstract}

Keywords: Studies, characteristics, Tinospora cordifolia, giloy

\section{Introduction}

India is one of the 17 mega biodiversity countries and contribute about 7 per cent of world biodiversity. Medicinal plants are found from Himalayan to marine and desert to rain forest ecosystems. Domestic demand of medicinal plants has been estimated 1,95,000MT whereas total consumption of herbal raw drug in the country for the year 2014-15 has been estimated $5,12,000 \mathrm{MT}$. The export demand of medicinal plants is estimated about 1,34,500 MT with export value of ₹3211 Crore during the same year (National Medicinal Plant Board).

Giloy contains good amount of nutritive composition of crude fibre (5.72 per cent) and ash content (6.35 per cent). It also comprised calcium and iron $(9.41$ and $0.29 \mathrm{mg} / 100 \mathrm{~g}$, respectively). The whole plant is used medicinally however; the stem is approved for use in medicine due to higher alkaloid content in the stems than in the leaves (Choudhary et al., 2013) ${ }^{[3]}$.

The pharmaceutical importance of giloy is because of antioxidant activity of various bioactive compounds such as alkaloids, terpenoids, lactose, glycosides, steroids, phenolics, aliphatic compounds and polysaccharide (Pradhan et al., 2013) ${ }^{[5]}$.

Giloy contain various bioactive compounds such as alkaloids, glycosides, lactones, steroids, polysaccharides and aliphatic compounds having various medicinal importance viz., antitumor, cognition, anti-inflammatory, antioxidant, gastrointestinal and anti-malarial, anti-allergic and side effects prevention of the cancer chemotherapy (Dwivedi and Enespa, 2016) ${ }^{[4]}$.

Medicinal plants can be dried in several ways: in direct contact with sunlight; placed in thin layers on drying frames, by drying in shade; in drying ovens/rooms and solar dryers; by indirect fire; microwave. In all these drying methods controlled temperature and humidity are required otherwise it may damage active chemical constituents. In medicinal plant drying retaining of active ingredients is more important than other properties. The method and temperature used for drying may have a considerable impact on the quality of drug in medicinal plant materials (Aboltins and Kic, 2016) ${ }^{[2]}$.

Currently, energy demand of drying represents a significant cost factor, especially with the increased price of fossil fuels. This is largely due to the high moisture content of the flowers, leaves or roots to be dried. 


\section{Materials and Methods}

\section{Procurement of raw material}

Giloy (Tinospora cordifolia) were collected from the CTAE farm, MPUAT Udaipur. The stem was harvested in the early morning hours in dry climate. The stems were kept in plastic bags and then carried to the experimental laboratory.

\section{Cleaning and Sorting}

The adhering soil particle to the Giloy stem were removed and sorted along proper size. Size selected based on its appearance of woody brown color and stem should not be too thick or too thin.

\section{Cutting}

The freshly harvested neem giloy were cut into $0.5 \mathrm{~cm}$ size carefully using a stainless steel knife. The size of stem was selected as $5 \mathrm{~mm}$ for the drying method.

\section{Initial moisture content of Giloy stem}

The initial moisture content of giloy stem was determined by oven drying method.An amount equal to $10 \mathrm{~g}$ of freshly harvested giloy stem sample was placed in thoroughly cleaned, dried and pre-weighed moisture boxes. The initial weight sample was recorded. The moisture boxes were put in the oven at $105^{\circ} \mathrm{C}$ temperature for $24 \mathrm{~h}$. The samples were then taken out of oven and cooled in the desiccators and weighed using an electronic balance having capacity of $200 \mathrm{~g}$ and least count of $0.001 \mathrm{~g}$. Initial and bone dried weights were used to calculate the initial moisture content which was expressed as $g$ water per $g$ dry matter.

\section{Drying method}

The convention method of drying for medicinal plant may pose difficulty in maintaining the product quality and less hygienic condition. Hence mechanical dryer namely convective tray dryer has been selected.

The air flow rate was varied as $1,1.5$ and $2 \mathrm{~m} / \mathrm{s}$ at three different temperatures $\left(40,50\right.$ and $\left.60{ }^{\circ} \mathrm{C}\right)$. The sample was weighed at varying intervals till the constant moisture content was achieved.

\section{Moisture content}

The reduction in moisture content of giloy stem was recorded at an interval of $10 \mathrm{~min}$ for first 70 minutes, then interval of $15 \mathrm{~min}$ for next $105 \mathrm{~min}$, and every $20 \mathrm{~min}$ from next hour time till the end of drying process.

\section{Drying rate}

The moisture content data recorded during experiments were analysed to determine the moisture lost from the dried giloy stem at a particular time interval. The drying rate of the sample was calculated by following the mass balance equation.

\section{Results and Discussion}

The weight of giloy slices during convective tray drying and infrared was recorded periodically and moisture content was determined by using mass balance equations.

\section{Initial Moisture Content}

The initial moisture content of giloy stem slices was determined by oven drying method. The average initial moisture content of giloy was found as 72.67 per cent (wet basis).

\section{Effect of air temperature on drying time}

The weight loss in the Giloy stem slices with elapsed drying time, at each air temperature and air velocity $(1,1.5$ and 2 $\mathrm{m} / \mathrm{s}$ ) is presented in the following figure which showed the moisture deduction pattern. As the drying air temperature increased, the drying curves exhibited steeper slope indicating that the drying rate increased with increase in drying air temperature. This resulted into substantial decrease of drying time.

Drying time for giloy stem slices under different condition The reduction in the drying time with increase in temperature was quite evident. With increase in temperature from $40{ }^{\circ} \mathrm{C}$ at air velocity $1 \mathrm{~m} / \mathrm{s}$ to $50^{\circ} \mathrm{C}$ with same air velocity, the reduction in time was 11.2 per cent and that for $60{ }^{\circ} \mathrm{C}$ the time reduction was 28.16 per cent as compared to $40{ }^{\circ} \mathrm{C}$ at same air velocity of $1 \mathrm{~m} / \mathrm{s}$.

Similarly at $60^{\circ} \mathrm{C}$ on increasing the air velocity from $1 \mathrm{~m} / \mathrm{s}$ to $2 \mathrm{~m} / \mathrm{s}$ the drying time reduces to about 23.5 per cent.

\section{Effect of drying air temperature and air velocity on moisture content}

The Giloy stem slices required 195 to 355 min to dry in tray drying to bring down initial moisture content ranging from 265.85 per cent $(\mathrm{db})$ to final moisture content in the range of 8.54 to 6.80 per cent (db). It can be seen that there was a wide variation in drying time ranging from 195 to $355 \mathrm{~min}$ for various drying air temperatures and air velocity taken for study. Moisture reduction was found to be temperature and air velocity dependent and is slow at lower temperature and took more time as compared to drying at higher temperatures. They also concluded that an increase in air velocities resulted to a higher drying rate; however, the effect of the drying velocity on the drying rate was nearly negligible for lower moisture ratios.

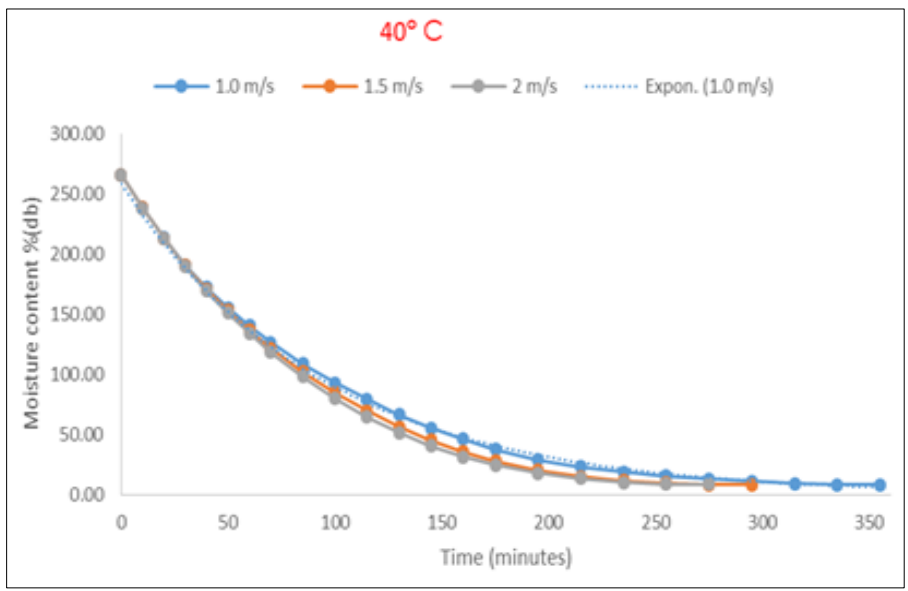

Fig 1: The effect of air velocity on moisture content (db) at temperature $40{ }^{\circ} \mathrm{C}$ 


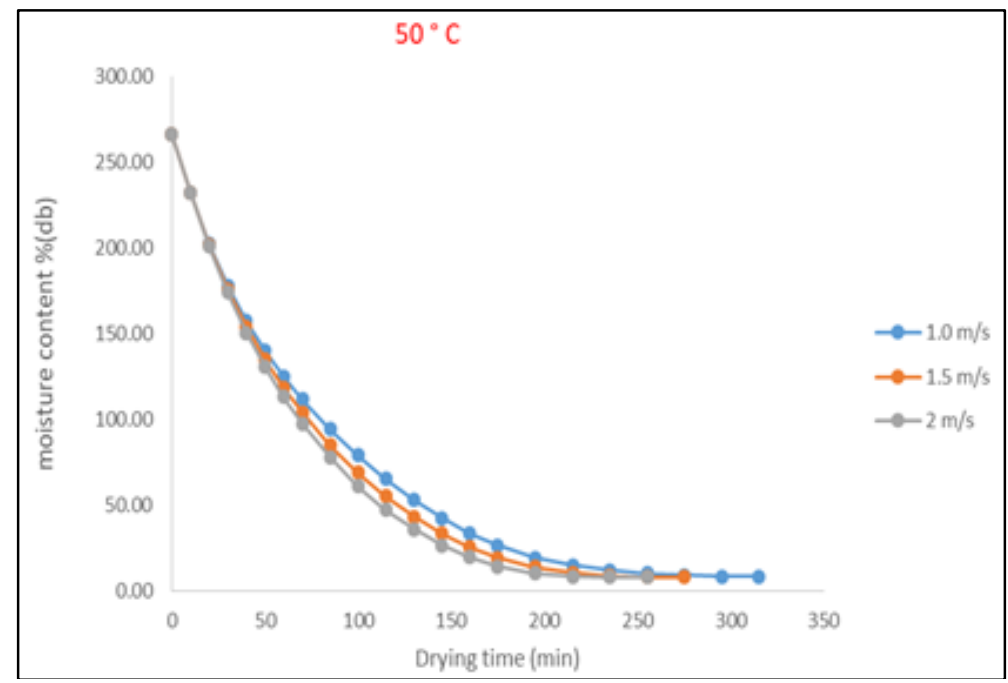

Fig 2: The effect of air velocity on moisture content $(\mathrm{db})$ at temperature $50{ }^{\circ} \mathrm{C}$

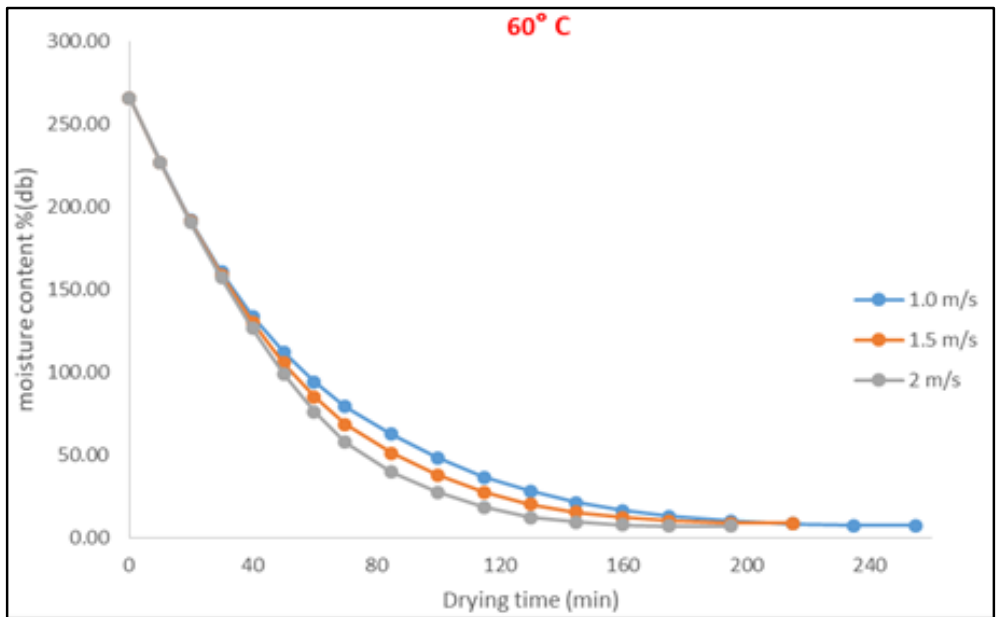

Fig 3: The effect of air velocity on moisture content $(\mathrm{db})$ at temperature $60{ }^{\circ} \mathrm{C}$

Effect of air temperature and air velocity on drying rate curves

The drying rate for Giloy stem slices had been estimated from the change in the moisture content values occurring in a given time interval and expressed as $\mathrm{g}$ water/g dry matter/h. It is quite evident from the figure that initial drying rate was higher for higher temperature value. It can be observed that the higher the air drying velocity the higher the drying rate.
However at lower moisture content, the effect of the velocity on the drying rate seems to be insignificant.

From the observation it can be seen that, constant rate-drying period was not found in drying curves. The entire drying process took place in the falling rate period; the curves typically demonstrated smooth diffusion controlled drying behaviour under all drying temperatures and air velocity.

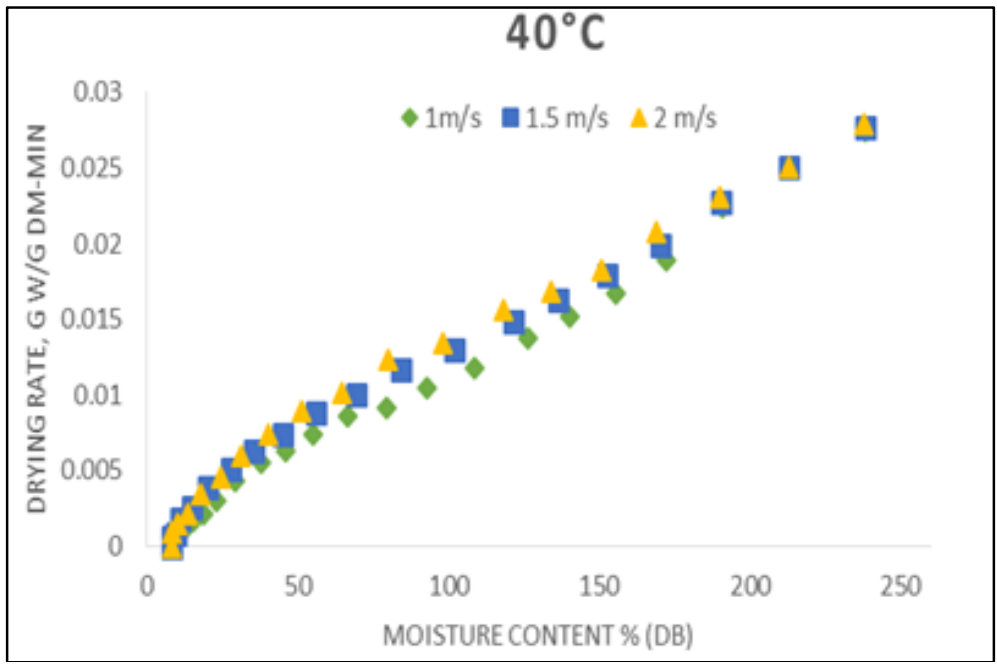

Fig 4: The effect of air velocity on drying rate of giloy stem at $40{ }^{\circ} \mathrm{C}$ 


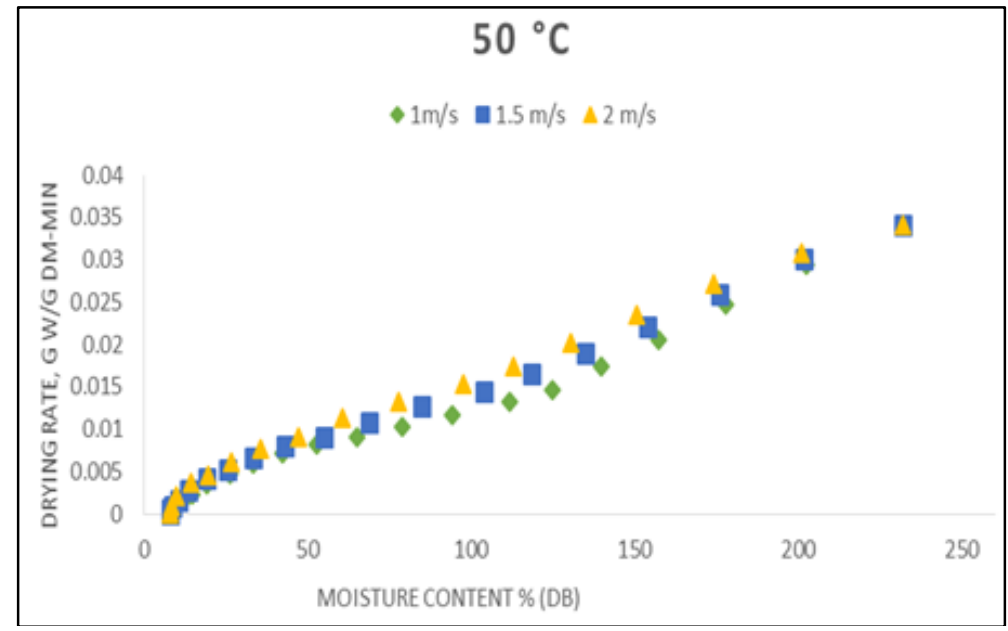

Fig 5: The effect of air velocity on drying rate of giloy stem at $50{ }^{\circ} \mathrm{C}$

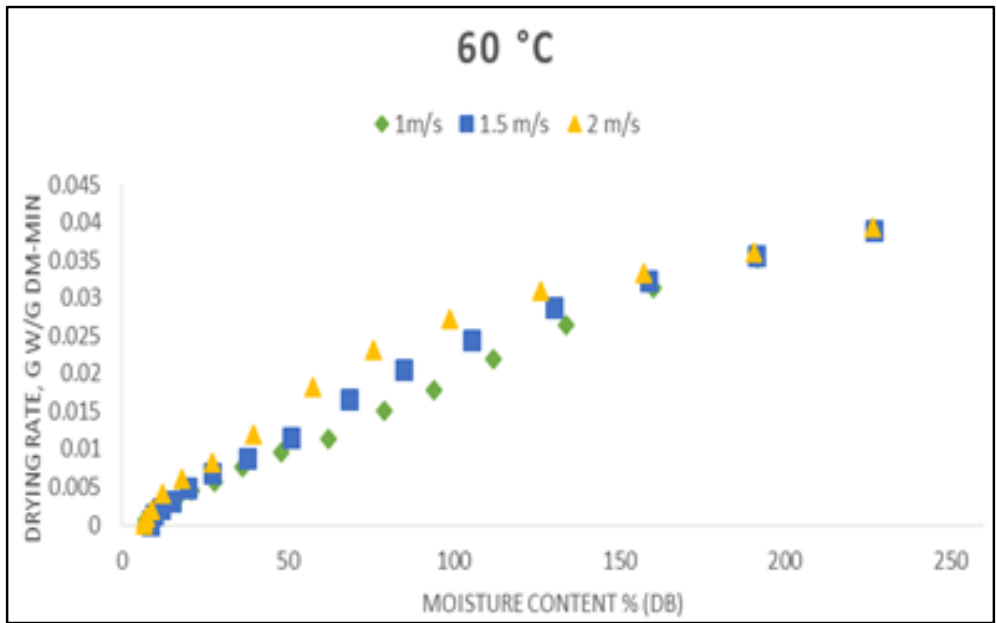

Fig 6: The effect of air velocity on drying rate of giloy stem at $60{ }^{\circ} \mathrm{C}$

\section{Conclusion}

The effect of process variable on the drying characteristics of giloy (Tinospora cordifolia) stem was successfully interpreted. The mechanical tray drying of giloy stem took place in falling rate period and was significantly influenced by air temperature and air velocity. The total drying time ranged between 195 minutes to 355 minutes and the final moisture content of dried stem was safe for further postharvest Process sing.

\section{References}

1. https://www.nmpb.nic.in/

2. Aboltins A, Pavel Kic P. Research in Some Medical Plant Drying Process. Engineering for Rural Development 2016;27:1145-1150.

3. Choudhary N, Siddiqui MB, Azmat S, Khatoon S. Tinospora Cordifolia: Ethnobotany, Phytopahrmalogy and Phytochemistry aspect. International Journal of Pharmaceutical science and research 2013;4:891-899.

4. Dwivedi SK, Enespa. Tinospora Cordifolia with Reference to Biological and Microbial Properties. International Journal of Current Microbiology and Applied Sciences 2016;5:446-465.

5. Pradhan D, Ojha V, Pandey AK. Phytochemical analysis of Tinospora cordifolia (Willd.) Miers ex Hook. f. and Thoms stem of varied thickness. International Journal of Pharmaceutical Sciences and Research 2013;4:30513056. 